\title{
IAMJ
}

INTERNATIONAL

AYURVEDIC

MEDICAL JOURNAL

\section{A ROLE OF AYURVEDIC MANAEGEMENT IN BLEPHAROSPASM w.S.r. NIMESHA - A CASE STUDY}

\section{$\underline{\text { Mukesh Kumar Gupta }}^{1}$, Anubha Jain ${ }^{2}$}

${ }^{1}$ Associate Professor and HOD, Department of Shalakya Tantra, Government Autonomous Dhanwantray Ayurved College, Ujjain, Madhya Pradesh, India

${ }^{2}$ Assistant Professor, Department of Shalakya Tantra, Government Autonomous Dhanwantray Ayurved College, Ujjain, Madhya Pradesh, India

Corresponding Author: drmukeshgupta95@gmail.com

\section{https://doi.org/10.46607/iamj2109062021}

(Published Online: June 2021)

Open Access

(C) International Ayurvedic Medical Journal, India 2021

Article Received: 08/05/2021 - Peer Reviewed: 02/06/2021 - Accepted for Publication: 04/06/2021

\section{Check for updates}

\section{ABSTRACT}

Ayurveda can provide effective and harmless relief for certain diseases which sometimes can't be cured with modern medicine. Nimesha is a condition, pertaining to Shalakya Tantra in which eye lids starts blinking involuntary due to influence of Vata Dosha. In this condition patients can't be able to focus things properly and having lots of discomfort. It can be correlated to blepharospasm i.e., an abnormal contraction of eye lid muscles, which is also refers to benign essential blepharospasm. It is thought to be rare, affecting about 16-133 cases per million. There is no cure for blepharospasm in modern practice. Generally, doctors inject botox injection into eyelid muscles which need to get injected in every 4-6 month, rather than permanent benefits it has lots of side effects like diplopia ectropion etc. Ayurveda can be useful in the treatment of blepharospasm and its complication that it is a Vataj Vyadhi all Vatashamak therapies could be effective for its treatment. A 61 years old male patient known case of bilateral blepharospasm was visited in OPD of Government Autonomous Dhanwantari Ayurveda Hospital, Ujjain. He had complained of excessive blinking with tired eye muscles, heaviness around eyes, headache, anxiety and irritation etc. for 3 years. He was on regular allopathic medicine along with botox injection around each eye which is repeated in every 6 months, but after few shots of treatment pt. didn't receive any benefits. 
Therefore, he came to us and after Ayurvedic treatment patient showed marked improvement in symptomatology, with limited abnormal eye lid movement and with negligible side effects. Here was $70 \%$ relief after Ayurvedic treatment.

Keyword: Ayurveda, Nimesha, Blepharospasm, Botox

\section{INTRODUCTION}

The eyes are our body's highly developed sensory organ. In fact, a far larger part of the brain is dedicated to vision than to hearing, touch, taste or smell combinedly. We tend to take eyesight for granted, yet when vision problem develops, most of us will do everything in our power to restore our eyesight back to normal. Structure of our eye resemble to a camera, if shutter of camera didn't work properly than we can't click perfect picture similarly if eye lids are not healthy than normal functioning of an eye can't be achieved. This similar thing tends to happen in Nimesha in which eye lids are not working properly. According to our Acharyas in Nimesha Vata Dosha reached to Nimilan Kaari Shira (nerve which helping in eye lid movement) and will lead to frequent eye lid movement and increase blinking occurs. ${ }^{1,2}$ This can be correlated to blepharospasm / eye twitching, which is a form of facial dystonia. It affects the muscles around the eyes, which may cause uncontrolled blinking, lid spasm or difficulty keeping the eyes open resulting sustained and forceful closure of the eyelids. Although the eye lid twitching may start on one side, the condition typically eventually affects both eyes. It occurs in two forms, one is essential (spontaneous) blepharospasm, which is a rare idiopathic and uncommon condition having insidious onset involving patients between 45 and 65 years of age and other is reflex blepharospasm, which is usually occurs due to reflex sensory stimulation through branches of fifth nerve, in conditions such as: phlyctenular keratitis, interstitial keratitis, corneal foreign body, corneal ulcers and iridocyclitis. It is also seen in excessive stimulation of retina by dazzling light and patient may complain of photophobia, a vague discomfort and a foreign body sensation. ${ }^{3}$ In blepharospasm persistent epiphora may occur due to spasmodic closure of the canaliculi which may lead to eczema of the lower lid. Oedema of the lids is of frequent occurrence. In severe cases, blepharospasm is disabling because it may temporarily render the patient functionally blind. Spasm may be precipitated by reading, driving, stress or bright light, and alleviated by talking, walking and relaxation. ${ }^{4}$ For treatment purpose in essential blepharospasm Botulinum toxin, injected subcutaneously over the orbicularis muscle which blocks the neuromuscular junction by interference with acetylcholine release from nerve terminals and relieves the spasm. Facial denervation of all temporal- zygomatic and buccal branches of the facial nerve which cause contraction of the upper facial muscle may be required in severe cases. In reflex blepharospasm, the causative disease should be treated to prevent recurrences. Associated complications should also be treated. Though Nimesha is Asadhya Vyadhi according to Ayurveda but Ayurvedic line of treatment can be helpful for such type of condition if we will treat is as Yapya Vyadhi. In this case study oral as well as local therapy such as Netra Pindi, Netra Vidalaka were given to the patient as mentioned in our Ayurvedic Samhita, which is having very good effects with lesser side effects. ${ }^{5}$

\section{Case Report}

A 61 years old male patient walked in OPD of Government Autonomous Dhanwantari Ayurveda Hospital, Ujjain

Patient name: XYZ

OPD No: 7419

Date of registration: 13/03/2021

Chief Complaints: Patient presented with the involuntary frequent movement of eye lid with pain and tiredness around the eye.

Associated Complaints: Patient having headache, irritation and anxiety, watering from eye. 


\section{H/O Present Illness:}

Patient was apparently normal 3 years ago, he suddenly presented with frequent blinking of eye lid. Initially it appeared occasionally with few abnormal blinking with mild pain around eye but later on attacks and frequency of blinking along with pain increased. But patient did not take this situation for granted and he didn't consult to any doctor and didn't take any medicine. After few shots of attacks this condition become permanent with few other symptoms such as sharp pain, heaviness around eye, lethargy, irritation etc., for which he took allopathic treatment for more than 2 years, in which initially he found some benefits but later on he didn't get any result rather than he faced some side effects too. Then he came to our OPD. to be treated with Ayurveda.

PAST HISTORY: No relevant history such as hypertension, hyperglycemia etc. was found.

\section{Personal History:}

He was working in railways department for approx. 30 years, but due to irregular duty hours his sleeping habits being disturbed and according to the patient this could be the precipitating cause of the disease and it is being very tough to him to continue this job with these painful symptoms; therefore he took V.R.S. (voluntary retirement scheme) two year before the actual time of retirement.

Family History: No relevant history found.

Medical History: He is treated with Procyclidine $5 \mathrm{mg}$ B.D., Gabapentine 100 mg O.D., Methylcoblamin $500 \mathrm{mcg}$ O.D. along with injection Botox 50 units around each eye in every 6 months for 4 times.

Ayurvedic Management: Though Nimesha is Asadhya Vyadhi according to Ayurveda but due to Vataj predominance it can be managed with Vatashamaka Chikitsa, therefore when patient came to us we first gave him Vatashamak Aushadha preceding with Deeapana and Pachana Chikitsa in form of oral medication as Panchkola Churna, Bruhatvaat Chinatamani Rasa, Vatakulantak Rasa, Praval Pishti, Jatamaaansi Churana with Sitopaladi Churna as it is having Yogwaahi property along with Panchtikta Ghruta Guggulu and Punarnava Guggulu. Besides these oral medicines some Kriyakalpas also advised him after three days of oral medicines in our Kriyakalp OPD as Nasya, Netra Pindi, Netra Bidalaka along with Sthaniya Snehan Swedana. Initially we gave him Anu tail Nasya for 3 days followed by Kshirbala tail Nasya which is having Brunhan properties. For local Snehana around eyes we used Khirbala 101 Avarti tail. Along with Nasya we prescribed him Netra Pindi for 10 min for 7 days with Gokshura Choorna, Jatamaansi Churna, Bala and Nirgundi Patra than after 5 days gape we prescribed him Netra Vidalaka with Harida, Mulethi, Bala Patra, Nirgundi Patra, and Kachnaar Twak Churna. after Vidalaka, Trapana with Mahatriphala Ghruta for 7 days advised.

\section{RESULT:}

After three days of oral medication patient showed some improvement in symptomatology. According to him he feels very relaxed after long time because limited abnormal lid movement and decreased muscular spasm lids. According to patient after all procedure he got approx. $75 \%$ relief in all symptoms. Among all symptoms he got maximum relief in muscular spasm which is more annoying than other symptoms. Abnormal blinking reduced up to 30-35 times / minute from 50-55 times in a minute.

\section{DISCUSSION}

As patient previously treated with allopathic medicine which were show little effect in initial phase but later no relief was obtain by patient. He received Botox injection around eye which is usually starts to work after a few days from the injection and generally takes a week for the full effect. Any beneficial effect last for two or three months before wearing off. ${ }^{6}$ Therefore, this injection needs repeating in every 5-6 month, progressively larger dose may be needed. It can weaken the contractions and block the nerve signals sent to and from the muscles surrounding the eye. Side effects include lagophthalmos and ectropion or entropion. Accidental migration of the toxin into the orbit may result in ptosis and diplopia due to paralysis of the levator or extraocular muscles. Other medicines received by the patients is may have fewer effects on neuralgia along with neurotonic effect, but these all not having satisfactory effect over disease. Ayurvedic 
medicines which be gave have some permanent effect with lesser expenses along with lesser side effects. Among them Panchkola Churna has digestive properties which enhances the proper digestion and also work as a appetizer. Both Guggulu having antiinflammatory and analgesic properties which cures the local pain and neuralgia. Rest other oral drug having Vata Shamana Guna therefore they all are having action on nerve which causing abnormal eyelid movement as Chala Guna of Dusit Vata Dosha is Shaman by all these drugs. Kriyakalpas which we prescribed to the patient also having Vatashamana effect. Among them Snehana with 101 Avarti Kshirbala Tail suppresses Vata Dosa and renourished to nerves, Netra Pindi and Netra Bidalaka have anti-inflammatory action and pressure effect which is also helping in reduction of abnormal movements and pain. Nasya with Anu Tail followed by Kshir Bala tail have Doshaj regulatory effect for all Doshas and nourished all Indriyas. These all therapy combinedly causes the Samprapty Vighatan of disease process and have some beneficial effect for not only to control disease but to rejuvenate all sense organ along with whole body.

\section{CONCLUSION}

Though Nimesha is Asadhya Vyadhi according to Ayurveda as well as from modern medicine too, we can treat it is as Yapya Vyadhi and treating such types of Vyadhi with Ayurveda may have positive results with very few side effects even though patient treating with Ayurveda can feels better as maximum Ayurvedic therapies showed rejuvenating effect on whole body. Similarly, it is happened with treatment of Nimesha as oral medicines given to the patient purify Vata from all over the body and Nasya Snehana Sodhana etc. local procedure cleans vitiated Doshas and nourish all sensory organs therefore in patient of Nimesha maximum symptoms are subsides along with whole body relaxation.

\section{REFERENCES}

1. Shastri Ambikadutta, Sushruta Samhita, Ayurveda Tattva Sandipika Hindi commentary, uttar tantra 3/25, Chaukhambha Sanskrit Sansthan Varanasi. Reprint 2009:P- 17
2. Upadhyaya Yadunandana, Ashtang Hrudayam, Vidyotiniy Hindi Commentary, Uttar Sthana 8/5, Chaukhambha Sanskrit Sansthan Varanasi. Reprint 2002:P475

3. Khurana A.K., Khurana I: Anatomy and Physiology of Eye;6thedi. (2015), CBS Publishers and Distributors, New Delhi. P - 362

4. Ramanjit sihota, Radhika Tandon: arsons' Disease of the eye; $19^{\text {th }}$ edition, Elsevier publisher, India. P-478

5. Jack J. Kanski: Clinical Ophthalmology, A systemic Approach; $5^{\text {th }}$ edition, Elsevier publisher, P-655

6. Beverley Attridge, Ophthalmic Nurse Specialist, East Sussex Healthcare NHS Trust - www.esht.nhs.uk, Botox Injections for Blepharospasm and Hemifacial spasm

\section{Source of Support: Nil \\ Conflict of Interest: None Declared}

How to cite this URL: Mukesh Kumar Gupta Anubha Jain: A Role Of Ayurvedic Management In Blepharospasm W.S.R. Nimesha -A Case Study. International Ayurvedic Medical Journal \{online\} 2021 \{cited June, 2021\} Available from: http://www.iamj.in/posts/images/upload/1283 1286.pdf 